\title{
The Supervisory Competencies of Physical Education Supervisors from the Point of View of Physical Education Teachers
}

\author{
Mo'een Ahmad Oudat \\ Faculty of Physical Education and Sport Science, The Hashemite University, Jordan \\ Received December 15, 2020; Revised January 18, 2021; Accepted February 24, 2021
}

\section{Cite This Paper in the following Citation Styles}

(a): [1] Mo'een Ahmad Oudat, "The Supervisory Competencies of Physical Education Supervisors from the Point of View of Physical Education Teachers," International Journal of Human Movement and Sports Sciences, Vol. 9, No. 2, pp. 185-193, 2021. DOI: 10.13189/saj.2021.090204.

(b): Mo'een Ahmad Oudat (2021). The Supervisory Competencies of Physical Education Supervisors from the Point of View of Physical Education Teachers. International Journal of Human Movement and Sports Sciences, 9(2), 185-193. DOI: $10.13189 /$ saj.2021.090204.

Copyright $\subseteq 2021$ by authors, all rights reserved. Authors agree that this article remains permanently open access under the terms of the Creative Commons Attribution License 4.0 International License

\begin{abstract}
The study aimed at identifying the level of the supervisory competencies of physical education supervisors from the point of view of (PE) teachers. The researcher applied the descriptive method, and the study population comprised all the male and female teachers of physical education in Irbid in the first semester of the academic year 2019/2020 $(\mathrm{n}=240)$. The study sample included (144) male and female teachers accounting for $(60 \%)$ of the study population. A questionnaire is designed to measure the level of the supervisory competencies of physical education supervisors from the point of view of (PE) teachers. It consisted of (24) items distributed over four domains (Personal competencies, curriculum development competencies, competencies for providing services required for the educational process, competencies for establishing human relations between workers). The coefficients of the instrument were calculated by using the content validity, and the total reliability coefficient amounted (0.88), and the data were processed by (SPSS). The results showed that the level of the supervisory competencies of physical education supervisors from the point of view of (PE) teachers was medium in all domains. The overall mean was (3.60) with (72.25) relative significance. And it also showed that there are no statistically significant differences in the level of the supervisory competencies of supervisors attributed to the gender variable. The results also showed that there are no statistically significant differences in the level of the
\end{abstract}

supervisory competencies of supervisors in the domains of (Personal competencies, competencies for providing services required for the educational process, competencies for establishing human relations between workers) Attributed to the variables of academic qualification and experience years. While it also showed that there are statistically significant differences in the level of supervisory competencies of supervisors in the domain of curriculum development competencies, and in favor of a higher academic qualification than a bachelor's, and experience less than 5 years.

Keywords Supervisory Competencies, Physical Education Supervisors, Physical Education Teachers

\section{Introduction}

The educational process has become an integrated whole not limited to providing information only, as was seen in the past. Rather, it aims to bring in comprehensive growth for the individual and raise his scientific level in thought, application and method, for the sake of the progress in building the society we all aspire and create the economic, social and political change. This view is not the responsibility of one party or individual, but there are many other parties who are also responsible (student, 
teacher, school management and the educational supervisor). They all share to achieve this goal as they work collectively as an integrated team to reach the desired purposes [1].

Educational supervision is one of the most important inputs in the educational system, being an educational leadership aiming at improving the teaching-learning process. It could be also viewed, from the system analysis side, as a series of interactions and events among the teacher, educational supervisor, student and principal [2]. Educational supervision contributes, to a wide extent, the improvement and development of the educational process, as the teachers' practices inside the classrooms rely on it. Through it, the curricula could be reconsidered and reviewed, the school management performance could improve and the promotion of the student's level could be reached. Therefore, the educational supervision is seen as a comprehensive process that covers all the practical educational aspects [3].

The educational supervision aims at achieving the school goals, and helping the workers in the educational field become skilful and of high educational competences in their performance [4]. It also helps in diagnosing the problems and errors, works to remedy them, and helps in developing and improving the performance levels inside the school. The teacher who performs teaching is in need to he who can direct, guide and supervise him to command the dealing methods with the students, to receive more experience in the teaching process, and to enable him face the continuous changes. In spite of applying the teacher preparation bases, and the teachers' desire to develop themselves, the educational supervisor who accompanies the teacher during service has the large role in the improvement and development of the teaching process. Accordingly, the quality and efficiency of the educational process relies on the quality, efficiency of the educational supervisor and the effectiveness of his systems. Hence, it can be said that the educational supervision and its operations are a major focus in achieving the quality management in education [5].

Recently, the educational supervision has taken a variety of forms in terms of its concept, aims and methods. After it was merely monitoring the students, evaluating their performance and hunting of their mistakes, many supervisory trends emerged, such as the scientific supervision that uses objective tests and standards in studying the educational situations inside and outside the classroom. There also appeared the provision of educational and technical services for the principals and administrators, which rendered the educational supervision a process that includes all the aspects of the educational process [6].

Physical education recently witnessed wide interest in the local and international forums, as it has, through its different activities, a role in supporting the educational system. It works on achieving the integrated and comprehensive growth of all the personal aspects. Thus, the educational curricula and the variety of their programs are most powerful factors that help in achieving the hopes and ambitions of the people. Furthermore, the idea of good teaching occupied a wide area in the educational field. Workers in this vital aspect showed good interest in an attempt to establish remedial paths to build acceptable rules of the skills of the educational process advancement and development [7].

It is clear from the above that it is necessary to improve the teaching efficiency of the teachers to achieve the physical education goals, in a manner that benefits the students and the whole community, all of which depend on the role of the educational supervisor. The researcher, through the results of the studies of [8]; [9]; [10] and the literature, sees that the educational supervision remained, for a period, using traditional educational methods that do not match the needs of the physical education teachers. For these reasons, the researcher made this study to identify the role of the educational supervisors in improving the competencies of the physical education teachers at schools. Through this study, the researcher attempts to identify the views of the physical education teachers about the role of the educational supervisor in improving the teachers' educational competencies.

\section{Study Problem}

The researcher, among other works, supervises the students of field training and has established relations with the teachers and supervisors of physical education. He strongly believes that the educational supervision has a great importance in the educational process, particularly in this age that is characterized by speed in all the walks of life. Furthermore, the educational supervision in our schools is still limited to traditional methods and practices that are far from the modern supervisory methods. Therefore, he made this study to identify the supervisory competencies of the physical education supervisors in the light of the total quality standards and the wide technological development.

\section{Study Significance}

The significance of this study is that it may contribute to the development of the performance of the educational supervisors, through identifying the supervisory competencies among PE supervisors. In addition, this study may be deemed a support of certain studies and research works that seek to develop the educational supervision in the sports field. In this regard, the supervisory competencies are a group of capabilities and skills that the educational supervisor possesses, which enable him perform his tasks, roles and responsibilities effectively and perfectly, which, in turn, will be reflected on the educational process as a whole, as well as his 
success and ability to communicate the information to the teachers through planning, preparation and application [11]. Educators emphasize the necessity to follow-up and evaluate all the workers in the educational field on an ongoing basis, to ensure the cognitive skills with them and support their strengths to achieve the planned targets [12], [13], [14].

\section{Objectives}

1. Identify the level of the supervisory competencies of physical education supervisors from the point of view of (PE) teachers by the study domains (Personal competencies, curriculum development competencies, competencies for providing services required for the educational process, competencies for establishing human relations between workers).

2. Identifying the differences in the level of the supervisory competencies of physical education supervisors from the point of view of (PE) teachers by the study by (gender, academic qualification, and experience years).

\section{Questions}

1. What is the level of the supervisory competencies of physical education supervisors from the point of view of (PE) teachers by the study domains (Personal competencies, curriculum development competencies, competencies for providing services required for the educational process, competencies for establishing human relations between workers)?

2. Are there statistically significant differences at $(\mathrm{P}<0.05)$ level in the level of the supervisory competencies of physical education supervisors from the point of view of (PE) teachers by the study by (gender, academic qualification, experience years)?

\section{Material and Methods}

\section{Participants}

The researcher used the descriptive approach, and the study population consisted of all physical education teachers in Irbid, who numbered (240) students. The sample of the study consisted of (144) male and female teachers, at a rate of $(60 \%)$ of the study population, which was chosen in a stratified random manner.

\section{Variables}

The independent variables are: gender (male, female), academic qualification (bachelor's and less, higher than bachelor's), experience years (less than 5 years, 5-10 years, more than 10 years). The dependent variables are: the domains of supervisory competencies (Personal competencies, curriculum development competencies, competencies for providing services required for the educational process, competencies for establishing human relations between workers).

\section{Instruments}

A special questionnaire was built to identify the level of the supervisory competencies of physical education supervisors from the point of view of (PE) teachers. The researcher benefited from a study [15]; [16]; [17]; [18]. The questionnaire included (24) phrases distributed in four domains (Personal competencies, curriculum development competencies, competencies for providing services required for the educational process, competencies for establishing human relations between workers). The researcher used the tripartite classification in measurement as follows: Mean (1.00-2.33) low level, Mean (2.34-3.66) Mean level, (3.67-5.00) high level. The questionnaire was distributed and collected between $5 / 1 / 2020-12 / 1 / 2020$ in the first semester of the academic year 2019/2020.

\section{Psychometric Properties}

Statistical analysis

Data analyses were performed by using (The instrument validity was verified by presenting it to four of specialists in physical education field, who made certain comments, which the researcher carried them out after making the required amendments. The reliability coefficient was calculated using Cronbach's Alpha (0.88). And using statistical package for social sciences (SPSS) to descriptive statistics (i.e., M, SD, Relative Importance Index (RII), t-test, and One-Way ANOVA, Scheffe' Test) to answer the questions.

\section{Results}

First question: "What is the level of the supervisory competencies of physical education supervisors from the point of view of (PE) teachers by the study domains (Personal competencies, curriculum development competencies, competencies for providing services required for the educational process, competencies for establishing human relations between workers)?" Tables $(1,2,3,4$, and 5) illustrate this: 
Table 1. Data of the participants (M, SD, and RII) of level of the supervisory competencies in the domain of Personal competencies

\begin{tabular}{|c|c|c|c|c|}
\hline Phrases & $\mathrm{M}$ & $\mathrm{SD}$ & $\mathrm{RII}$ & Level \\
\hline $\begin{array}{c}\text { The educational supervisor } \\
\text { possesses high abilities and } \\
\text { qualifications }\end{array}$ & 3.86 & 0.93 & $\mathbf{7 7 . 2 0}$ & High \\
\hline $\begin{array}{c}\text { The educational supervisor } \\
\text { possesses good personal and } \\
\text { leading traits }\end{array}$ & 3.72 & 1.21 & $\mathbf{7 4 . 4 0}$ & High \\
\hline $\begin{array}{c}\text { The educational supervisor } \\
\text { follows-up applying the } \\
\text { curriculum content }\end{array}$ & $\mathbf{3 . 6 5}$ & 1.11 & 73.00 & Medium \\
\hline $\begin{array}{c}\text { The educational supervisor can } \\
\text { determine the needs of the } \\
\text { educational programs }\end{array}$ & $\mathbf{3 . 6 0}$ & 1.02 & 72.00 & Medium \\
\hline $\begin{array}{c}\text { The educational supervisor can } \\
\text { identify the challenges that } \\
\text { face the teachers and help them } \\
\text { to overcome and solve them }\end{array}$ & $\mathbf{3 . 5 5}$ & 1.18 & 71.00 & Medium \\
\hline $\begin{array}{c}\text { The educational supervisor } \\
\text { encourages teachers to perform } \\
\text { innovative skills }\end{array}$ & $\mathbf{3 . 5 1}$ & 1.20 & 70.20 & Medium \\
\hline Overall Average & 3.65 & 1.11 & 72.97 & Medium \\
\hline
\end{tabular}

The overall average of the level of the supervisory competencies of physical education supervisors from the point of view of (PE) teachers that is related to the Personal competencies domain was medium $(\mathrm{m}=3.65)$ with (72.97) relative importance. The first and second phrases were with high level, and the remaining phrases were with medium level.

Table 2. Data of the participants (M, SD, and RII) of level of the supervisory competencies in the domain of curriculum development competencies

\begin{tabular}{|c|c|c|c|c|}
\hline Phrases & M & SD & RII & Level \\
\hline $\begin{array}{c}\text { The educational supervisor } \\
\text { possesses modern educational } \\
\text { ways and methods }\end{array}$ & 3.84 & 1.12 & 76.80 & High \\
\hline $\begin{array}{c}\text { The educational supervisor } \\
\text { views the study plans set by } \\
\text { the teachers }\end{array}$ & $\mathbf{3 . 7 4}$ & 0.95 & 74.80 & High \\
\hline $\begin{array}{c}\text { The educational supervisor } \\
\text { follows the teachers' } \\
\text { application of the study plans }\end{array}$ & $\mathbf{3 . 6 7}$ & 0.98 & 73.40 & High \\
\hline $\begin{array}{c}\text { The educational supervisor is } \\
\text { keen on teachers' application } \\
\text { of the modern teaching } \\
\text { methods }\end{array}$ & $\mathbf{3 . 5 4}$ & 1.17 & 70.80 & Medium \\
\hline $\begin{array}{c}\text { The educational supervisor } \\
\text { evaluates the performance of } \\
\text { the teachers' teaching }\end{array}$ & $\mathbf{3 . 5 0}$ & 1.14 & 70.00 & Medium \\
\hline $\begin{array}{c}\text { The educational supervisor } \\
\text { provides the teachers with the } \\
\text { most important results of the } \\
\text { research and studies to make } \\
\text { use of them in teaching }\end{array}$ & $\mathbf{3 . 4 5}$ & 1.04 & 69.00 & Medium \\
\hline Overall Average & 3.62 & 1.07 & 72.47 & Medium \\
\hline
\end{tabular}

The overall average of the level of the supervisory competencies of physical education supervisors from the point of view of (PE) teachers that is related to the curriculum development competencies domain was medium $(\mathrm{m}=3.62)$ with $(72.47)$ relative importance. The first three phrases were with high level, and the remaining phrases were with medium level.

Table 3. Data of the participants (M, SD, and RII) of level of the supervisory competencies in the domain of competencies for providing services required for the educational process

\begin{tabular}{|c|c|c|c|c|}
\hline Phrases & M & SD & RII & Level \\
\hline $\begin{array}{c}\text { The educational supervisor } \\
\text { understands the problems } \\
\text { that face the teaching } \\
\text { process }\end{array}$ & $\mathbf{3 . 7 9}$ & 1.13 & 75.80 & High \\
\hline $\begin{array}{c}\text { The educational supervisor } \\
\text { listens to the teachers' needs } \\
\text { and suggestions. }\end{array}$ & 3.73 & 1.04 & 74.60 & High \\
\hline $\begin{array}{c}\text { The educational supervisor } \\
\text { works with the school } \\
\text { management to prepare a } \\
\text { suitable environment to } \\
\text { apply the educational } \\
\text { activities. }\end{array}$ & $\mathbf{3 . 6 4}$ & 1.09 & 72.80 & Medium \\
\hline $\begin{array}{c}\text { The educational supervisor } \\
\text { continuously follows-up the } \\
\text { progress of the teaching } \\
\text { process }\end{array}$ & 3.56 & 1.24 & 71.20 & Medium \\
\hline $\begin{array}{c}\text { The educational supervisor } \\
\text { provides solutions to address } \\
\text { weakness of the curricula }\end{array}$ & $\mathbf{3 . 4 4}$ & 1.16 & 68.80 & Medium \\
\hline $\begin{array}{c}\text { The educational supervisor } \\
\text { provides modern thoughts } \\
\text { for teachers to use in } \\
\text { teaching }\end{array}$ & $\mathbf{3 . 4 0}$ & 1.06 & 68.00 & Medium \\
\hline Overall Average & 3.59 & 1.12 & 71.87 & Medium \\
\hline
\end{tabular}

The overall average of the level of the supervisory competencies of physical education supervisors from the point of view of (PE) teachers that is related to the competencies for providing services required for the educational process domain was medium $(\mathrm{m}=3.59)$ with (71.87) relative importance. The first and second phrases were with high level, and the remaining phrases were with medium level.

Table 4. Data of the participants (M, SD, and RII) of level of the supervisory competencies in the domain of competencies for establishing human relations between workers

\begin{tabular}{|c|c|c|c|c|}
\hline Phrases & M & SD & RII & Level \\
\hline $\begin{array}{c}\text { The educational supervisor } \\
\text { respects and appreciates the } \\
\text { teacher }\end{array}$ & $\mathbf{3 . 7 3}$ & 0.91 & 74.60 & High \\
\hline $\begin{array}{c}\text { The educational supervisor } \\
\text { is keen on building } \\
\text { relations with teachers and } \\
\text { school management. }\end{array}$ & $\mathbf{3 . 6 8}$ & 1.19 & 73.60 & High \\
\hline $\begin{array}{c}\text { The educational supervisor } \\
\text { possesses methods of } \\
\text { reinforcement for teachers }\end{array}$ & 3.62 & 1.11 & 72.40 & Medium \\
\hline $\begin{array}{c}\text { The educational supervisor } \\
\text { treats the problems related } \\
\text { to the administrative } \\
\text { matters }\end{array}$ & 3.49 & 1.08 & 69.80 & Medium \\
\hline $\begin{array}{c}\text { The educational supervisor } \\
\text { takes into account the } \\
\text { individual differences } \\
\text { among teachers }\end{array}$ & $\mathbf{3 . 4 2}$ & 1.07 & 68.40 & Medium \\
\hline $\begin{array}{c}\text { The educational supervisor } \\
\text { holds regular meetings for } \\
\text { the teachers with each other }\end{array}$ & $\mathbf{3 . 3 8}$ & 1.13 & 67.60 & Medium \\
\hline Overall Average & 3.55 & 1.08 & 71.70 & Medium \\
\hline
\end{tabular}


The overall average of the level of the supervisory competencies of physical education supervisors from the point of view of (PE) teachers that is related to the competencies for establishing human relations between workers domain was medium $(\mathrm{m}=3.55)$ with $(71.70)$ relative importance. The first three phrases were with high level, and the remaining phrases were with medium level.

Table 5. Data of the participants (M, SD, and RII) in the domains of level of the supervisory competencies in a descending order

\begin{tabular}{|c|c|c|c|c|}
\hline Domain & $\mathrm{M}$ & $\mathrm{SD}$ & $\mathrm{RII}$ & Level \\
\hline Personal competencies & 3.65 & 1.11 & 72.97 & Medium \\
\hline $\begin{array}{c}\text { Curriculum } \\
\text { development } \\
\text { competencies }\end{array}$ & 3.62 & 1.07 & 72.47 & Medium \\
\hline $\begin{array}{c}\text { Competencies for } \\
\text { providing services } \\
\text { required for the } \\
\text { educational process }\end{array}$ & 3.59 & 1.12 & 71.87 & Medium \\
\hline $\begin{array}{c}\text { Competencies for } \\
\text { establishing human } \\
\text { relations between } \\
\text { workers }\end{array}$ & 3.55 & 1.08 & 71.70 & Medium \\
\hline Overall Average & 3.60 & 1.10 & 72.25 & Medium \\
\hline
\end{tabular}

The overall average of the supervisory competencies of physical education supervisors from the point of view of $(\mathrm{PE})$ teachers was medium $(\mathrm{m}=3.60)$ with $(72.25)$ relative importance.

Second Question: "Are there statistically significant differences at $(p \leq 0.05)$ level in the level of the supervisory competencies of physical education supervisors from the point of view of (PE) teachers by the study by (gender, academic qualification, and experience years)?" Tables (6, $7,8,9$, and 10) illustrate this:

Table 6. Data of the participants (t-test) of level of the supervisory competencies by gender

\begin{tabular}{|c|c|c|c|c|c|}
\hline Domain & Gender & Mean & SD & $\mathrm{T}$ & P-Value \\
\hline \multirow{2}{*}{$\begin{array}{c}\text { Personal } \\
\text { competencies }\end{array}$} & Male & 3.69 & 1.14 & \multirow{2}{*}{0.69} & \multirow{2}{*}{0.490} \\
\hline & Female & 3.61 & 1.05 & & \\
\hline \multirow{2}{*}{$\begin{array}{c}\text { curriculum } \\
\text { development } \\
\text { competencies }\end{array}$} & Male & 3.65 & 0.98 & \multirow{2}{*}{0.42} & \multirow{2}{*}{0.678} \\
\hline & Female & 3.59 & 1.09 & & \\
\hline \multirow{2}{*}{$\begin{array}{l}\text { competencies for } \\
\text { providing } \\
\text { services required } \\
\text { for the } \\
\text { educational } \\
\text { process }\end{array}$} & Male & 3.68 & 1.15 & \multirow[b]{2}{*}{1.38} & \multirow[b]{2}{*}{0.170} \\
\hline & Female & 3.50 & 1.01 & & \\
\hline \multirow{2}{*}{$\begin{array}{l}\text { competencies for } \\
\text { establishing } \\
\text { human relations } \\
\text { between workers }\end{array}$} & Male & 3.59 & 0.95 & \multirow[b]{2}{*}{0.96} & \multirow[b]{2}{*}{0.340} \\
\hline & Female & 3.51 & 1.08 & & \\
\hline
\end{tabular}

There are no statistically significant differences at $(p \leq 0.05)$ level in the level of the supervisory competencies of physical education supervisors from the point of view of (PE) teachers attributed to the gender variable. $\mathrm{T}$ values ranged between $(0.42-1.38)$, and the level of significance was $(\mathrm{p} \leq 0.05)$ for all the domains of the supervisory competencies.

Table 7. Data of the participants (t-test) of level of the supervisory competencies by academic qualification

\begin{tabular}{|c|c|c|c|c|c|}
\hline Domain & $\begin{array}{c}\text { academic } \\
\text { qualification }\end{array}$ & Mean & SD & $\mathrm{T}$ & P-Value \\
\hline \multirow{2}{*}{$\begin{array}{c}\text { Personal } \\
\text { competencies }\end{array}$} & BA and less & 3.54 & 0.95 & \multirow[b]{2}{*}{0.65} & \multirow[b]{2}{*}{0.521} \\
\hline & $\begin{array}{c}\text { Higher of } \\
\text { BA }\end{array}$ & 3.70 & 0.87 & & \\
\hline \multirow{2}{*}{$\begin{array}{c}\text { curriculum } \\
\text { development } \\
\text { competencies }\end{array}$} & BA and less & 3.45 & 0.94 & \multirow[b]{2}{*}{1.23} & \multirow[b]{2}{*}{0.021} \\
\hline & $\begin{array}{c}\text { Higher of } \\
\text { BA }\end{array}$ & 3.79 & 1.02 & & \\
\hline \multirow[b]{2}{*}{$\begin{array}{c}\text { competencies } \\
\text { for providing } \\
\text { services } \\
\text { required for } \\
\text { the } \\
\text { educational } \\
\text { process }\end{array}$} & BA and less & 3.54 & 1.13 & \multirow[b]{2}{*}{1.28} & \multirow[b]{2}{*}{0.205} \\
\hline & $\begin{array}{l}\text { Higher of } \\
\text { BA }\end{array}$ & 3.64 & 1.10 & & \\
\hline \multirow[b]{2}{*}{$\begin{array}{c}\text { competencies } \\
\text { for } \\
\text { establishing } \\
\text { human } \\
\text { relations } \\
\text { between } \\
\text { workers }\end{array}$} & BA and less & 3.48 & 1.08 & \multirow[b]{2}{*}{0.80} & \multirow[b]{2}{*}{0.425} \\
\hline & $\begin{array}{l}\text { Higher of } \\
\text { BA }\end{array}$ & 3.62 & 1.03 & & \\
\hline
\end{tabular}

Table (7) Shows that there are no statistically significant differences in the level of the supervisory competencies of physical education supervisors from the point of view of (PE) teachers attributed to academic qualification variable in the domains of (Personal competencies, competencies for providing services required for the educational process, competencies for establishing human relations between workers). While it showed statistically significant differences at the significance level $(\mathrm{p} \leq 0.05)$ in the level of supervisory competencies in the domain of curriculum development competencies, and in favor of a higher academic qualification than a BA. T values ranged between $(0.65-1.28)$, and the level of significance was $(\mathrm{p} \leq 0.05)$ for all the domains of the supervisory competencies.

Table 8. Data of the participants (t-test) of level of the supervisory competencies by experience years

\begin{tabular}{|c|c|c|c|}
\hline Domain & $\begin{array}{c}\text { experience } \\
\text { years }\end{array}$ & Mean & SD \\
\hline \multirow{3}{*}{ Personal competencies } & Less than 5 & $\mathbf{3 . 6 2}$ & 1.18 \\
\cline { 2 - 4 } & $5-10$ & $\mathbf{3 . 6 3}$ & 1.10 \\
\cline { 2 - 4 } & More than 10 & $\mathbf{3 . 7 0}$ & 0.98 \\
\hline \multirow{2}{*}{$\begin{array}{c}\text { curriculum development } \\
\text { competencies }\end{array}$} & Less than 5 & $\mathbf{3 . 7 8}$ & 1.20 \\
\cline { 2 - 4 } & $5-10$ & 3.52 & 0.92 \\
\cline { 2 - 4 } & More than 10 & $\mathbf{3 . 5 6}$ & 1.01 \\
\hline \multirow{2}{*}{$\begin{array}{c}\text { competencies for providing } \\
\text { services required for the } \\
\text { educational process }\end{array}$} & Less than 5 & 3.54 & 1.12 \\
\cline { 2 - 4 } & $5-10$ & 3.61 & 1.17 \\
\cline { 2 - 4 } & More than 10 & 3.62 & 0.97 \\
\hline $\begin{array}{c}\text { competencies for } \\
\text { establishing human } \\
\text { relations between workers }\end{array}$ & Less than 5 & 3.50 & 1.08 \\
\cline { 2 - 4 } & $5-10$ & 3.55 & 1.09 \\
\cline { 2 - 4 } & More than 10 & 3.60 & 1.13 \\
\hline
\end{tabular}


Statistically significant differences at $(\mathrm{p} \leq 0.05)$ level in the level of the supervisory competencies of physical education supervisors from the point of view of (PE) teachers attributed to experience variable. To determine if there are statistically significant differences at $(p \leq 0.05)$ level among the means, the One-Way ANOVA analysis was applied, as illustrated in Table (9).

There are statistically significant differences at $(p \leq 0.05)$ level in the level of the supervisory competencies of physical education supervisors from the point of view of (PE) teachers attributed to the variable of experience years. To determine the sources of differences, Scheffe post-hoc test was applied, as shown in Table (10).

Statistically significant differences at $(\mathrm{p} \leq 0.05)$ level in the level of the supervisory competencies of physical education supervisors from the point of view of (PE) teachers attributed to experience variable. The differences were in (curriculum development competencies) domain, which were in favor of the experience less than 5 years.

\section{Discussion}

The results showed that the supervisory competencies level of the physical education supervisors, as viewed by the PE teachers, was medium. This result is attributed to that PE supervisors have supervisory competencies in the different domains. In the personal competencies domain, the educational supervisor's possession of the high scientific qualifications, his personal traits and leading skills have a positive effect on the educational process outcomes. The researcher is in line with [19] in that the educational supervisor's possession of personal competencies and leading skills contribute to the building of human and social relations among the parties of the educational process, and to the creation of a spirit of cooperation among them. On the other hand, this study is not in line with [20] who provided that there is weakness in the supervisory process of the educational supervisors that they perform their supervisory competencies at a low level, and there is weakness in their supervisory competencies as well.

In developing the curricula competencies, the educational supervisor who has modern educational methods and ways, as well as good planning, can make a positive effect on amending the plans and the educational modules, using alternative educational tools, and proper acting in the different situations. The researcher is in line with [21] in that the educational supervisor has a wide role in finding alternatives of the weakness of the curricula.

Table 9. Data of the participants (One Way ANova) of level of the supervisory competencies by experience years

\begin{tabular}{|c|c|c|c|c|c|c|}
\hline Domain & $\begin{array}{l}\text { Source of } \\
\text { Variance }\end{array}$ & $\begin{array}{l}\text { Sum of } \\
\text { Squares }\end{array}$ & Gl & $\begin{array}{c}\text { Mean } \\
\text { Squares }\end{array}$ & $\mathrm{F}$ & P-Value \\
\hline \multirow{3}{*}{ Personal competencies } & Inter-Groups & 471.38 & 4 & 56.102 & \multirow{3}{*}{0.316} & \multirow{3}{*}{1.167} \\
\hline & Intra- Groups & 2776.39 & 570 & 4.713 & & \\
\hline & Total & 3289.54 & 574 & & & \\
\hline \multirow{3}{*}{ curriculum development competencies } & Inter-Groups & 231.68 & 4 & 56.283 & \multirow{3}{*}{0.012} & \multirow{3}{*}{0.757} \\
\hline & Intra- Groups & 2789.78 & 570 & 5.214 & & \\
\hline & Total & 3142.54 & 574 & & & \\
\hline \multirow{3}{*}{$\begin{array}{l}\text { competencies for providing services required for } \\
\text { the educational process }\end{array}$} & Inter-Groups & 125.47 & 4 & 2.542 & \multirow{3}{*}{0.101} & \multirow{3}{*}{2.346} \\
\hline & Intra- Groups & 2457.23 & 570 & 2.874 & & \\
\hline & Total & 2156.88 & 574 & & & \\
\hline \multirow{3}{*}{$\begin{array}{c}\text { competencies for establishing human relations } \\
\text { between workers }\end{array}$} & Inter-Groups & 526.84 & 4 & 14.621 & \multirow{3}{*}{0.089} & \multirow{3}{*}{2.477} \\
\hline & Intra- Groups & 3486.25 & 570 & 6.358 & & \\
\hline & Total & 3421.54 & 574 & & & \\
\hline
\end{tabular}

Table 10. Sheffe results of the (post-comparisons) of level of the supervisory competencies by experience years

\begin{tabular}{|c|c|c|c|c|c|}
\hline Domain & Mean & experience years & Less than 5 & $5-10$ & More than 10 \\
\hline \multirow{3}{*}{$\begin{array}{c}\text { curriculum development } \\
\text { competencies }\end{array}$} & $\mathbf{3 . 7 8}$ & Less than 5 & & & \\
\cline { 2 - 6 } & 3.52 & $5-10$ & & & \\
\cline { 2 - 6 } & $\mathbf{3 . 5 5}$ & More than 10 & $*$ & & \\
\hline
\end{tabular}


As for providing the required services to the educational process, there is an effect of the educational supervisor who has ability to deal with the different situations, listen to the teachers' needs and suggestions, provide a suitable environment to apply the educational activities, and suggest solutions for the problems and obstacles that face the teachers during teaching. The researcher is in agreement with [22] in that the ability of the educational supervisor to use communication skills with the teachers effectively can contribute to providing the required services to the educational process and solving many of the problems they face.

In the area of the competencies of establishing human relations among the workers, the respectful dealing of the educational supervisors with the teachers, and taking into account the individual differences among them has a great effect in promoting and motivating them to work. These positive elements also had effect on dealing with their administrative related problems through holding regular meeting with them. The researcher is in line with [23] in that the human relations that are based on the mutual respect between the educational supervisor and the teachers enhance the trust of the teachers, and motivate them to put make more efforts to achieve the educational process targets.

The researcher imputes the absence of differences in the supervisory competencies levels with the supervisor according to the gender variable to that both genders have the desire to prove their abilities to achieve. In this concern, the researcher is in line with [24], who provided that both male and female teachers have the same attitudes toward the educational supervisors. On the other hand, our study is not in line with [25], whose results showed differences in the level of the supervisory competencies among the educational supervisors attributed to the gender variable, in favor of the males. He ascribes the differences to that the male supervisors are more capable than the female to discuss, dialogue and determine the level of the supervisory competencies.

The researcher ascribes the differences in the supervisory competencies level among the supervisors according to the academic degree, in the domain of developing the curricula, to that the teachers with higher academic degrees have more knowledge about the developed curricula, and are able to analyze them and deal with the errors and obstacles that face their implementation in proportion of the age stages. In this domain, the researcher is in line with [26] in that the teachers with higher academic qualifications are more knowledgeable of the competencies, skills and abilities the educational supervisors hold. The teachers can benefit these advantages from the educational supervisors in a better manner than those who hold lower academic qualifications, in terms of the use of the developed curriculum and all whatever new and related to it.

Finally, the researcher ascribes the lack of differences in the supervisory competencies level with the supervisors according to the academic degree in all the domains of the supervisory competencies, except for the curricula development, to that all the teachers have personal traits that enable them to establish human relations with the students, and run the educational process effectively. On the other hand, the researcher ascribes the differences in the supervisory competencies according to the academic degree variable, in the domain of the competencies in the development of the curricula, to that the novice teachers are characterized by enthusiasm and high motivation, and have good knowledge of the modern methods in teaching and in their better use of technology in dealing with the new methods. They had already studied many subjects that utilize all whatever new. Therefore, they can benefit from the educational supervisors better than others. In this respect, the researcher is in line with [27], [28] in that the new teachers have received modern teaching and instructions to plan and implement the lesson in a better way.

\section{Conclusions}

The level of the supervisory competencies of physical education supervisors from the point of view of (PE) teachers was medium in all domains (Personal competencies, curriculum development competencies, competencies for providing services required for the educational process, competencies for establishing human relations between workers). And there are no differences in the level of the supervisory competencies of physical education supervisors from the point of view of $(\mathrm{PE})$ teachers attributed to the gender variable. Also there are no differences in the level of the supervisory competencies of physical education supervisors from the point of view of (PE) teachers in the domains of (Personal competencies, competencies for providing services required for the educational process, competencies for establishing human relations between workers) attributed to academic qualification variable. And there are a statistically significant differences in the level of supervisory competencies in the domain of curriculum development competencies, and in favor of a higher academic qualification than a bachelor's. While, there are no differences in the level of the supervisory competencies of physical education supervisors from the point of view of (PE) teachers in the domains of (Personal competencies, competencies for providing services required for the educational process, competencies for establishing human relations between workers) attributed to experience variable. And there are statistically significant differences in the level of supervisory competencies in the domain of curriculum development competencies, and in favor of the experience years less than 5 years. 


\section{Recommendations}

Activating the role of educational supervisors to benefit from their supervisory competencies and expand their role and relations with the parties to the educational process (director, teacher, curriculum, and student) and preparation of plans that will be implemented during the year, in proportion to the existing capabilities and conducts periodic visits to the school, and conducting workshops or training courses for teachers on an ongoing basis to face scientific and technological development in various fields, and motivate and encourage teachers to develop their performance. Finally, conducting studies are similar to the current study with other variables.

\section{Limitations}

The study has several limitations. First, the way the researcher chose the study sample which was by Stratified random method. Second, the results are generalizable only to the target population and to the same setting (i.e., physical education teachers in Irbid in Jordan). Finally, the results of the study were based on perspective of the participants themselves.

\section{Acknowledgments}

No external financial support was received for this study. The authors would like to thank all the volunteers who participated in this study for their participation in assisting with data collection.

\section{REFERENCES}

[1] Abu Jame', Q. M. The Role of Educational Supervisors in Improving the Competencies of Physical Education Teachers in Public Schools in Gaza Governorates in Light of Comprehensive Quality Standards, Unpublished Master Thesis, Al-Azhar University, Gaza, 2013.

[2] Nashwan, J. Educational Administration and Supervision between Theory and Practice, Amman, Dar Al-Furqan for Publishing and Distribution, 1986.

[3] Al-Sherbiny, G. The role of educational supervision in achieving quality in public education in the Kingdom of Saudi Arabia, a study presented at the fourth annual meeting of the Saudi Society for Educational and Psychological Sciences, Buraidah, King Sau'd University, 2007.

[4] Ahmed, A. Modernization of Educational Administration, Optometry and Technical Supervision, New Publications House, Egypt, 1988.

[5] Craig, J. G. A short scale to evaluate supervision and supervisor competence-The SE-SC8, Clinical Psychology Psychotherapy, pp.1-10, 2020.
[6] Al-Buhi, F. Opinions of Basic Education Instructors and Teachers on Technical Supervision, A Comparative Study of Alexandria Governorate, Journal of the Alexandria College of Education, First Issue, Alexandria, 1992.

[7] Casolo, F.; Daniele, C.; Gabriella, F.; Paola, V. \& Casolo, A. Effective Teaching Competences in Physical Education, Journal of Physical Education and Sport, Vol. 19, No. 5, pp. 1806-1813, 2019.

[8] Ali, S. A. \& Bakr, A. Y. A comparative study in the level of teaching competencies between males and females according to the academic achievement of physical education teachers, Al-Fath journal, Issue 70, pp. 77-91, 2017.

[9] Jabbar, F. A. Teaching competencies of physical education teachers and their relationship to the acquisition of some motor skills for students in middle schools, an Unpublished Master Thesis, College of Basic Education, Diyala University, Iraq, 2011.

[10] Tarawneh, M. H. The teaching competencies possessed by the trained teacher students in cooperating schools from the viewpoint of the cooperating teachers, Dirasat: Educational Sciences, Vol. 42, No. 3, pp. 807-819, 2015.

[11] Al-Dreij, M. Competencies in education, for the scientific establishment of the integrated curriculum, Ramses Publications, Knowledge for All Series, pp 81, 2000.

[12] Muhammad, M. Recent trends in teaching physical education and sports, Artistic Radiology, Cairo, 2001.

[13] Al-Muslim, B. Competencies of elementary school teachers in Kuwait (A Comparative Study), Journal of Education and Development, Second Year, pp. 31, 2013.

[14] Al-Nuri, A. Modern trends in educational administration in the Arab countries, Cairo, House of Culture, 1991.

[15] Carol, A. F, \& Edward, S. Competence in Competency-Based Supervision Practice: Construct and Application, Professional Psychology Research and Practice, Vol. 38, No.3, pp. 232-240, 2007. DOI: 10.1037/0735-7028 .38.3.232.

[16] Al-Hamdon, M. The Role of Physical Education Supervisors in Developing School Sports for Education Directorates from the Teachers' Point of View in Mafraq Governorate, Journal of the Association of Arab Universities for Education and Psychology, Vol. 14, No. 2, pp. 84-109, 2016.

[17] Oudat, M. A. \& Al-Tahayneh, Z. The Effect of Educational Supervision Styles on Performance Effectiveness of Physical Education Teachers in Jordanian Public Schools from Teachers' Perspectives, Majallat al-'Ulum al-Tarbawiyyat wa-al-Nafsiyyat, Vol. 15, No. 2, pp. 81-100, 2014.

[18] Rababeh, J. \& Al-Reqeb, K. Evaluating the patterns of educational supervision of physical education supervisors from the point of view of physical education teachers in the Directorate of Education in the Qweismeh District, Dirasat: Educational Sciences, Vol. 46, No.1, pp. 701-719, 2019.

[19] Bhargava, A. \& Pathy, M. Perception of Student Teachers about Teaching Competencies, American International Journal of Contemporary Research, Vol. 1, No.1, pp. 77- 81, 2011. 
[20] Craig, J. G.; Geaty, H.; Nicole, M. S.; S \& Danielle, L. The Supervision Evaluation and Supervisory Competence Scale: Psychometric Validation, Australian Psychological Society, 52, pp. 94-103, 2017.

[21] Klara, B., Sarah, M. \& Lars, O. Developing a community of practice around teaching: a case study, Higher Education Research and Development, Vol. 27, No. 2, pp. 121- 132, 2008 .

[22] Al-Sharif, E. Evaluation of Student, Teacher Teaching Competencies in the Curricula and Teaching Methods of Motor Expression in the Light of Quality Academic Standards, World Journal of Sport Sciences, 3 (S), pp. 331-358, 2010.

[23] Tarawneh, R. The degree of availability of supervisory competencies among educational supervisors in scientific subjects in private schools in the capital, Amman, and their relationship to the morale of teachers from their point of view. Unpublished Master Thesis, Middle East University, College of Educational Sciences, Jordan, 2017.

[24] Al-Maqid, A. The reality of the supervisory practices of the educational supervisors of the UN Relief Agency in Gaza in light of the principles of comprehensive quality and ways to develop it, an Unpublished Master Thesis, The Islamic University, Gaza, 2006.

[25] Al-Ghafli, A. The reality of applying the principles of total quality in educational supervision by educational supervisors, College of Education, Department of Curricula and Teaching Methods, Um Al-Qura University, 2011.

[26] Abu Ryala, M. M. The reality of the administrative practices of UNRWA school principals in the governorates of Gaza and their relationship to the level of morale of teachers. Unpublished Master Thesis, Islamic University, Gaza, 2016.

[27] Yousef, A. H. Teaching competencies needed to prepare a physical education teacher from their point of view, Scientific Journal of the Sciences and Techniques of Physical and Sports Activities, Vol. 8, No. 8, pp. 17-34, 2011.

[28] Belhamel, K. Estimating the level of teaching aptitudes of primary school teachers, Unpublished Master Thesis, Mohamed Khaider University, Faculty of Social and Human Sciences, Biskra, Algeria, 2015. 